\title{
Impact of capital structure on firm value: Evidence from Tehran Stock Exchange
}

\author{
Atena Moghadas", Abbas Ali Pouraghajan and Vanoosheh Bazugir
}

Department of Accounting, Science and Research Branch, Islamic Azad University, Mazandaran, Iran

\begin{tabular}{l}
\hline C H R O N I C L E \\
\hline Article history: \\
Received January 22, 2013 \\
Received in revised format \\
26 April 2013 \\
Accepted 20 May 2013 \\
Available online \\
May 26 2013 \\
\hline Keywords: \\
Firm value \\
Capital structure \\
Asset growth \\
\hline
\end{tabular}
A B S T R A C T

\begin{abstract}
This paper presents an empirical study on the effects of various factors on firm value including capital structure, firm size, asset growth, etc. The proposed study gathers the necessary information from selected firms listed on Tehran Stock Exchange over the period 2006-2010. In our study, all firms maintained the same fiscal calendar and there were active during the period of study. The results of our study indicate that there was a meaningful relationship between capital structure and firm value. In addition, there was a meaningful relationship between asset growth and increase on firm value. However, our study did not show any meaningful relationship between firms' size as well as revenue growth and firms' value.
\end{abstract}

(C) 2013 Growing Science Ltd. All rights reserved.

\section{Introduction}

One of the primary concerns on measuring the firm value is to find out about the effects of different factors influencing on it and there are literally various studies in this regard (Ross, 1977; Welch, 2004). Cheng et al. (2010) investigated whether there was an optimal leverage in which the firm was capable of maximizing its value or not. The results confirmed that a triple-threshold impact did exist and demonstrated an inverted-U correlation between leverage and firm value. The study also stated that it was possible to detect the definitive level beyond which a further increase in debt financing did not improve proportional firm value. Modigliani and Miller (1958) demonstrated the effect of debtequity ratio on firm value in their capital structure theory. There are many studies spent to develop new thoughts around this theory. Despite the effort accomplished by Modigliani \& Miller (1958) their model is still in vague. Chowdhury and Chowdhury (2010) attempted to empirically support the argument of Modigliani \& Miller. The work examined the impact of debt-equity structure on the value of shares given various sizes, industries and growth opportunities with the companies incorporated in Dhaka Stock Exchange (DSE) and Chittagong Stock Exchange (CSE) of Bangladesh.

*Corresponding author. Tel : +989113002814

E-mail addresses: tana_sea60@yahoo.com (A. Moghadas)

C 2013 Growing Science Ltd. All rights reserved.

doi: $10.5267 / \mathrm{j} . \mathrm{ms} 1.2013 .05 .040$ 
Dehaghani et al. (2013) presented a study to measure the impacts of privatization on some selected firms listed on Tehran Stock Exchange. The study selected eleven relatively big sized Iranian firms whose structures were privatized prior year 2011 and considered whether there was a meaningful relationship between ownership structure and enterprise value of privatized firms. They collected the necessary information before and after privatization process completed and using a regression model examined the main hypothesis as well as five sub-hypotheses. The results of the survey indicated that the number of major shareholders had been reduced after privatization process accomplished, the number of shares had no effect on firms' values. In addition, non-board members' duty did not influence on firms' value before and after privatization process, institutional investors did not play important role before and after privatization process, and separations played important role on firms' value before and after privatization occurred.

Asle et al. (2013) investigated the relationship between Tobin's Q and illiquidity in some selected firms in Tehran Stock Exchange. The proposed study selected non-financial stocks over the period of 2001-2010. The result of the survey indicated that there was a negative relationship between illiquidity and Tobin's Q but the ratio was approximately seven percent. Neghabi and Rafiee (2013) investigated the relationship between capital structure as dependent variable and seven independent variables including tax rate, firms' growth rate, fixed assets, firms' size, operating risk, profitability and industry type. Zarandi and Mozdabadi (2012) measured the effect of the market size and the ratio of book value on market value on excessive return. They used linear regression analysis to investigate the relationship between the excessive return and other factors and reported that there was a negative relationship between size and excessive return and a positive relationship between the ratio of $\mathrm{BV} / \mathrm{MV}$ and excessive return.

\section{The proposed study}

The proposed study of this paper presents an empirical study on the effects of various factors on capital structure. The proposed study gathers the necessary information from selected firms listed on Tehran Stock Exchange over the period 2006-2010. The main hypothesis of this paper is as follows,

1. There is a relationship between capital structure (financial leverage) and companies' market value.

There are also three sub-hypotheses associated with the proposed study of this paper as follows,

1. There is a relationship between revenue growth and companies' market value.

2. There is a relationship between size of companies and companies' market value.

3. There is a relationship between assets growth and companies' market value.

In gathering the information for this study, we only concentrate on those firms' whose fiscal calendar were started in March and they were active during the period of study and actively reported their financial statement on timely basis. We were also skeptical about our selection strategy and focused only on firms with no change on their total equities. Therefore, we only selected 58 firms for the proposed study of this paper. There are four independent variable including debt ratio (d), which is calculated as a ratio of total liabilities on total assets, revenue growth $(\mathrm{g})$, which is calculated on yearly basis, size of the firms (s), which is calculated by taking the natural logarithm on total assets and finally, asset growth (p), which is calculated as relative growth on total assets on yearly basis. The closing price of the firms is considered as dependent variable in our study. In order to perform regression technique, we first need to make sure that all independent variables are normally distributed. Table 1 shows details of some basic statistics on independent as well as dependent variables. 
Table 1

The summary of some basic statistics

\begin{tabular}{lccccc}
\hline Variable & Capital structure & Stock price & Firm size & Revenue growth & Assets growth \\
\hline Numbers & 290 & 290 & 290 & 290 & 290 \\
Mean & .6739 & 4437.4310 & 26.7517 & 16.2316 & 12.4964 \\
Standard deviation & .27878 & 6369.64346 & 1.70484 & 41.58428 & 54.91562 \\
Absolut min deviation & .107 & .265 & .149 & .159 & .260 \\
Maximum deviation & .107 & .233 & .096 & .159 & .260 \\
Minimum deviation & -.058 & -.265 & -.149 & -.087 & -.251 \\
Kolmogorov-Smirnov & 1.138 & .509 & .985 & .707 & 1.142 \\
P-value & .073 & .562 & .333 & .463 & .082 \\
\hline
\end{tabular}

As we can observe from the results of P-value for five variables of this study, we can conclude that all of them have been normally distributed. Therefore, we can perform regression analysis on this study. Next, we need to make sure that there are no auto-correlation ratio and all coefficient are statistically significance. Table 2 summaries the results of our survey on some necessary statistics.

Table 2

The summary of some basic statistics

\begin{tabular}{ccccc}
\hline Durbin-Watson & S.E. of regression & Adjusted R Square & R Square & R \\
\hline 1.707089 & 0.176704 & 0.351145 & 0.353398 & .59447 \\
\hline
\end{tabular}

Based on the results of Table 2, we can conclude that there is no auto-correlation among independent variables since Durbin-Watson is within an acceptable limit. Adjusted R-Square is equal to 0.35, which means the regression function could describe approximately $35 \%$ of changes on dependent variable by independent variable. Next, we need to find out whether we should use random or fixed effect method and this could be accomplished using Correlated Random Effects - Hausman Test. In this test, the null hypothesis assumes random effect while the alternative hypothesis is associated with fixed effect. Table 3 demonstrates the summary of our findings,

Table 3

Test cross-section random effects

\begin{tabular}{llll}
\hline Test Summary & Chi-Sq. Statistic & Chi-Sq. d.f. & Prob. \\
\hline Cross-section random & 4.061261 & 4 & 0.3978 \\
\hline
\end{tabular}

\section{The results}

In this section, we present details of our findings on testing various hypotheses of this study. We first present details of ANOVA test.

Table 4

The summary of ANOVA test

\begin{tabular}{llccccc}
\hline Model & Source of change & Sum of Square & df & Mean of Square & F & P-value \\
\hline \multirow{2}{*}{1} & Regression & $3.635 \mathrm{E} 8$ & 1 & $3.635 \mathrm{E} 8$ & & \\
& Residual & $1.136 \mathrm{E} 10$ & 288 & 39451077.518 & 9.214 & $.003^{\mathrm{a}}$ \\
\hline \multirow{2}{*}{ Model } & Total & $1.173 \mathrm{E} 10$ & 289 & & & P-value \\
\hline \multirow{2}{*}{2} & Source of change & Sum of Square & $\mathrm{df}$ & Mean of Square & F & \\
& Regression & $5.437 \mathrm{E} 8$ & 2 & $2.718 \mathrm{E} 8$ & 6.977 & $.001^{\mathrm{b}}$ \\
& Residual & $1.118 \mathrm{E} 10$ & 287 & 38960719.975 & & \\
\hline
\end{tabular}

The results of Table 4 show that both regression models are valid. Therefore, we can precede the regression estimation and the results are summarized in Table 5. 
Table 5

The results of regression analysis

\begin{tabular}{|c|c|c|c|c|c|c|c|}
\hline \multirow{2}{*}{$\mathrm{Y}$} & & \multirow{2}{*}{ Variables } & \multicolumn{2}{|c|}{ Nonstandard coefficients } & \multirow{2}{*}{$\begin{array}{c}\text { standard } \\
\text { coefficients }\end{array}$} & \multirow{2}{*}{$\mathrm{T}$} & \multirow{2}{*}{ P-Value } \\
\hline & & & $\mathrm{B}$ & Error & & & \\
\hline \multirow{5}{*}{ Firm's value } & \multirow{3}{*}{1} & Intercept & 7148.636 & 966.338 & & 7.398 & 0 \\
\hline & & Structure capital & -4022.97 & 1325.328 & -0.176 & -3.035 & 0.003 \\
\hline & & Intercept & 6978.858 & 963.553 & & 7.243 & 0 \\
\hline & \multirow[t]{2}{*}{2} & Structure capital & -4037.67 & 1317.083 & -0.177 & -3.066 & 0.002 \\
\hline & & Asset growth & 14.379 & 6.686 & 0.124 & 2.151 & 0.032 \\
\hline $\begin{array}{l}1 \\
2\end{array}$ & \multicolumn{2}{|r|}{$\mathrm{R}$} & \multicolumn{2}{|c|}{$\begin{array}{l}0.176 \\
0.215\end{array}$} & $\mathrm{R}^{2}$ & \multicolumn{2}{|c|}{$\begin{array}{l}0.031 \\
0.046\end{array}$} \\
\hline
\end{tabular}

Table 5 summarizes the results of regression analysis for two models. The first model considers the relationship between firms' value as dependent variable and structure capital as independent variable. For the second model, firm's value is a function of structure capital and asset growth. The results of tstudent values indicate that both model's coefficients are statistically meaningful when the level of significance is five percent.

\section{Conclusion}

We have presented an empirical to study the effects of various factors including capital structure, firm size as well as revenue and asset growth on firm value. The proposed study gathers the necessary information from selected firms listed on Tehran Stock Exchange over the period 2006-2010. The study has implemented linear regression technique and validates the results based on different statistical tests such as Durbin-Watson. The results of our study have indicated that it was possible to find the firm value of the firms based on capital structure. In addition, there was a meaningful relationship between asset growth and increase on firm value. However, our study did not show any meaningful relationship between firms' size as well as revenue growth and firms' value. The results of this survey are consistent with earlier results presented by Cheng et al. (2010) and Chowdhury and Chowdhury (2010).

\section{References}

Asle, H., Valahzaghard, M \& Ahranjani, B. (2013). A survey on the relationship between stock liquidity with firm performance: A case study of Tehran Stock Exchange. Management Science Letters, 3(2), 635-640.

Cheng, Y. S., Liu, Y. P., \& Chien, C. Y. (2010). Capital structure and firm value in China: A panel threshold regression analysis. African Journal of Business Management, 4(12), 2500-2507.

Chowdhury, A., \& Chowdhury, S. P. (2010). Impact of capital structure on firm's value: Evidence from Bangladesh. Business and Economic Horizons, (03), 111-122.

Dehaghani, M., Rostami, A., Faradonbeh, M., Faradonbeh, F \& Javanbakht, A. (2013). A study of the effect of change on ownership structure on enterprise value of privatized firms: Evidence from Tehran Stock Exchange. Management Science Letters, 3(5), 1459-1466.

Modigliani, F., \& Miller, M.H. (1958). The cost of capital, corporate finance and the theory of investment. American Economic Review, 48(3), 261-297.

Neghabi, Z \& Rafiee, S. (2013). Investigating different influential factors on capital structure of different sectors of industries listed in Tehran Stock Exchange. Management Science Letters, 3(1), 73-80.

Ross, S. A. (1977). The determination of financial structure: the incentive-signalling approach. The Bell Journal of Economics, 23-40.

Welch, I. (2004). Capital structure and stock returns. Journal of Political Economy, 112(1), 106-132.

Zarandi, H \& Mozdabadi, S. (2012). A study on the effect of size and ratio of book value to market value on excessive return. Management Science Letters, 2(8), 6037-3072. 